\title{
HEPATITIS B VACCINE EFFICACY IN PATIENTS WITH CHRONIC LIVER DISEASE BY HEPATITIS C VIRUS
}

\author{
Angelo Alves de MATTOS, Eliana Buksztejn GOMES, Cristiane Valle TOVO, \\ Cláudio Osmar Pereira ALEXANDRE and José Oscar dos Reis REMIÃO
}

\begin{abstract}
Background - Considering the immunosuppression of patients with chronic liver disease, their response to vaccination is discussed in literature. Aims - To evaluate the response of hepatitis B vaccine in patients with chronic hepatitis C virus infection. Methods - This is a prospective study in which 85 patients with chronic hepatitis $C$ virus infection ( $46.8 \pm 9.4$ years, $44.7 \%$ males) and 46 healthy adults ( 36.7 \pm 11.1 years; $39.1 \%$ males) were evaluated. Confirmation of hepatitis $\mathrm{C}$ virus was obtained by the technique of polymerase chain reaction. Viral load was determined by the branched DNA method in 74 patients, and genotype was determined by sequencing in 73 patients. All patients and healthy adults received three doses of Engerix $\mathrm{B}^{\circledR}$ vaccine IM (at 0,30 and 180 days). Serological responses to the vaccine were divided into three categories: seroprotection, when anti-HBs was $\geq 100 \mathrm{mUI} / \mathrm{mL}$; seroconversion, when anti-HBs was $10-99 \mathrm{mUI} / \mathrm{mL}$, and non-reagent, when anti-HBs was $<10 \mathrm{mUI} / \mathrm{mL}$. Results - The response of hepatitis B vaccine as determined 1 month following dose 3 was seroprotection in $37.7 \%$, seroconversion in $17.6 \%$ and non-reagent in $44.7 \%$ among patients and $84.8 \%, 13.0 \%, 2.2 \%$, respectively in healthy adults. The number of non-reagent responses was significantly higher among those patients with chronic liver disease. Sixty-five patients with chronic hepatitis were compared to 20 compensated cirrhotic patients in concern to the response to vaccine, but no difference was found. The response to vaccine in patients with genotypes 2 or $3(n=40)$ was better than in those with genotype $1(n=33)$. Response was not related to serum HCV-RNA concentration. Conclusion - The number of non-responders was higher in patients with chronic hepatitis $\mathrm{C}$ virus infection, irrespective of histological status and viral load. It is suggested that such patients should receive a double dose of vaccine, particularly the ones with genotype 1 .
\end{abstract}

HEADINGS - Hepatitis B vaccines. Liver diseases. Hepacivirus.

\section{INTRODUCTION}

Infection by hepatitis B virus (HBV) in a patient with chronic liver disease (CLD) appears to accelerate the preexisting liver damage ${ }^{(14,31)}$, making it critical to protect this population against the infection.

Individuals with liver disease seem to show a decreased response to $\mathrm{HBV}$ vaccine, but the evaluation of this population of patients is usually performed in transplantation centers, thus including patients with more severe liver diseases ${ }^{(5,8,22,34,35,36)}$.

Despite the increased severity of HBV infection in patients with chronic liver disease, few studies have been performed in patients with compensated disease. Special attention must be given to patients with chronic liver disease caused by hepatitis $\mathrm{C}$ virus (HCV) because it accounts for $70 \%$ of the cases of CLD $^{(11)}$. In the 1997 NIH Consensus Conference, vaccination of these patients was already recommended ${ }^{(26)}$.

Due to the scarcity of studies about vaccination for $\mathrm{HBV}$ in this population ${ }^{(2,18,20,38)}$ as well as the lack of studies assessing the response in relation to HCV genotype, we found it valuable to appreciate the response to the vaccine in these patients.

This study was designed to investigate the immunogenic response of the vaccine against $\mathrm{HBV}$ in patients with CLD by hepatitis $\mathrm{C}$ virus, as well as the role of the histological status of the disease and of HCV genotype and viral load in the response to vaccination.

\section{MATERIALS AND METHODS}

This study was performed at "Irmandade Santa Casa de Misericórdia" of Porto Alegre, RS, Brazil, where 125 anti-HCV positive patients were prospectively selected for evaluation of the response to the vaccine against HBV from May, 1999 to May, 2001.

Confirmation of anti-HCV status was obtained by polymerase chain reaction (PCR), and presence of chronic hepatitis or cirrhosis was determined through clinical, laboratory, ultrasonographic, endoscopic, and/or anatomopathological standards ${ }^{(3)}$.

Cirrhotic patients were sorted using the original classification proposed by Child-Turcotte and modified by $\mathrm{Pugh}^{(28)}$.

As a control group, 46 healthy volunteers working in a public organization in the same city were evaluated.

All patients had their height and weight recorded at the beginning of the study, and their body mass index (BMI) was calculated by dividing patient's weight $(\mathrm{kg})$ by the squared height

From the Department of Gastroenterology of "Fundação Faculdade Federal de Ciências Médicas" of Porto Alegre (FFFCMPA) and "Irmandade Santa Casa de Misericórdia de Porto Alegre" (ISCMPA), Brazil

Address for correspondence: Dr. Angelo Alves de Mattos - Rua Aurélio Bitencourt 35/201 - 90430-080 - Porto Alegre, RS, Brazil. E.mail: hmb@santacasa.tche.br 
$\left(\mathrm{m}^{2}\right)$. Patients were also inquired about their drinking and smoking behavior. An individual was considered as an alcoholic if he/she would drink at least $40 \mathrm{~g}$ of alcohol/day (males) and $20 \mathrm{~g} /$ day (females) for at least 5 years. For smokers, the number of cigarettes and the duration of the habit were recorded.

The exclusion criteria were: transplanted patients or those on waiting lists, chronic renal patients, HIV-positive patients, patients with neoplasias, immunosuppressed patients in general or those submitted to antiviral therapy with interferon for the last 3 months, pregnant women, and patients under 18 or over 70 years of age. Individuals already immunized against hepatitis B (presence of anti-HBs) or those previously exposed to HBV (presence of anti-HBc $\operatorname{IgM}$ or $\operatorname{IgG}$ ) were also excluded.

All anti-HBc and anti-HBs negative patients who would not match the exclusion criteria and who would agreed to participate in the study had their blood sampled for identification of HCV-RNA by PCR and blood biochemistry (aminotransferases, albumin, prothrombin time, alkaline phosphatase, and bilirubin). Additional samples were stored at $-80^{\circ} \mathrm{C}$ for later viral quantification by the branched DNA method (in which the cut-off value was $2.760 \mathrm{MEq} / \mathrm{mL}$ ) and genotype determination by direct sequencing of products obtained from the amplification by PCR.

All patients and volunteers received $20 \mu \mathrm{g}$ recombinant DNA vaccine (Engerix $\left.\mathrm{B}^{\circledR}\right)$ intramuscular administered at three different times $(0$, 30 , and 180 days) at the deltoid region.

Quantitative determination of anti-HBs antibodies and blood biochemistry were performed one month following dose 3 in both groups of study.

Seroprotection (SP) was considered if anti-HBs levels were equal to or above $100 \mathrm{mUI} / \mathrm{mL}$, seroconversion (SC) if anti-HBs levels were between 10 and 99, and non-reagent response (NR) if anti-HBs levels were below $10 \mathrm{mUI} / \mathrm{mL}$. Later a new response variable was created in which those who showed SP and SC would considered as responders and the ones who were NR would be considered as non-responders.

Local and systemic side effects related to the vaccine were documented up to 3 days following the administration of each dose of vaccine.

Detection of HBsAg was performed through the third generation Microparticle Immunoenzymatic Test $\mathrm{AxSYM}^{\circledR} \mathrm{HBs}_{\mathrm{Ag}}(\mathrm{v} 2)$, the presence of anti-HBc was detected by the Microparticle Immunoenzymatic Test AxSYM ${ }^{\circledR}$ Core $^{\circledR}$, and anti-HBs was quantitatively detected by the Microparticle Immunoenzymatic Test AxSYM ${ }^{\circledR}$ Ausab $^{\circledR}$, all of them from Abbott Diagnostics Division, Illinois, USA.

Anti-HCV was detected by the Microparticle Immunoenzymatic Test (MEIA) AxSYM ${ }^{\circledR}$ HCV version 3.0 (Abbott Diagnostics Division, Illinois, USA).

For confirmation of infection by hepatitis C virus the HCV Amplicor ${ }^{\circledR}$ test (Roche Diagnostic Systems, Inc., Brachburg, NJ, USA) was used, which is a direct test with DNA probes using the technique of DNA amplification through PCR. For quantification of hepatitis $C$ virus, the method of second generation branched DNA (b-DNA) signal amplification Quantiplex ${ }^{\circledR}$ HCV RNA 2.0 (Chiron Diagnostics. California, USA) was used, which is a sandwich hybridization assay of nucleic acids in soluble phase employing branched DNA molecules. The quantification limit of the test is $0.200 \mathrm{MEq} / \mathrm{mL}$ of HCV RNA. Samples with values below this threshold are considered as negative. Samples with values above $120 \mathrm{MEq} / \mathrm{mL}$ are out of the safety limit of the test standard curve and must be diluted so that a reliable quantitative value can be obtained. For HCV genotype determination it was used the method of automatic sequencing, which is performed using the PCR amplification product (from region 5' non-encoded). The ABI prism 377 sequencer was used (Perkin-Elmer Applied Biosystems, Foster City, California, USA).

This study was submitted to and approved by the Ethics Committee of "Irmandade Santa Casa de Misericórdia" of Porto Alegre, RS, Brazil, and all participants authorized their blood sample collection.

Patient and control groups were compared in relation to continuous variables with Student's $t$ test for independent samples and chi-square test for categorical variables. For anti-HBs variables and viral quantification by branched DNA, non-parametric Mann-Whitney test was used. Graphic depiction of these comparisons was performed through box diagrams. For the evaluation of the role of age as a confusing factor in the association between illness and vaccinal response, a logistic regression was performed and included group and age in a forced entrance model. The outcome variable was considered as "response" (SC $+\mathrm{SP})$. For all these comparison levels of significance was $5 \%$.

\section{RESULTS}

Of the 125 patients participating of this study, 85 completed the three doses of vaccination and performed the required tests. Nineteen patients did not return after the second dose of vaccine, 15 did not return after the third dose, and 6 initiated therapy with interferon before completion of the vaccination schedule. No losses occurred in the control group. Patients' mean age was $46.8 \pm 9.4$ years ( $28-67$ years), 38 were males $(44.7 \%)$, and $80(94 \%)$ were caucasian.

Liver histology was performed in 56 patients. Minor histological alterations were detected in 4 patients, 24 had chronic hepatitis with low activity and/or portal fibrous expansion, 11 had moderate activity and/or septal fibrosis, 2 had intense activity and/or bridged fibrosis, and 15 had cirrhosis.

In regard to the other 29 patients, in 24 the diagnosis of chronic liver disease was established when patients showed positive PCR for HCV. In these cases alanineaminotransferase (ALT) was persistently normal or at levels as high as one and a half times below the upper value of normality, reason why biopsy was not performed. In the other five patients cirrhosis diagnosis was based on clinical, laboratory, ultrasonographic, and endoscopic standards.

The mean age in the control group $(\mathrm{n}=46)$ was $36.7 \pm 11.1$ years (19-60 years), with 18 (39.1\%) males and $45(97.8 \%)$ caucasian.

One month following dose 3 of vaccine, $37 \%$ of patients showed SP, $17.6 \%$ showed SC, and $44.7 \%$ were NR and, among volunteers, the values were $84.8 \%, 13.0 \%$, and $2.2 \%$, respectively (Figure 1 ). The percentage of NR was significantly higher in patients with liver disease $(P<0.001)$. The odds ratio observed for NR in patients in relation to volunteers was 46.31 with confidence interval (CI) of $95 \%$ from 6.21 to 956.19 .

Anti-HBs levels ranged from $<10$ to $>1000 \mathrm{mUI} / \mathrm{mL}$ in patients, with median equal to 12.8 , and from $<10$ to $>1000 \mathrm{mUI} / \mathrm{mL}$ in volunteers, with median $>1000$ (Figure 2). Anti-HBs levels were significantly higher in volunteers $(P<0.001)$

A difference was found between the mean age of patients and volunteers $(P<0.001)$. A logistic regression was performed to evaluate its role as a confusing factor in the comparison between patients' and volunteers' response to vaccine. The model showed that age was not significantly associated to response $(P=0.28)$ when it was controlled for the presence or absence of the HCV in the individual $(P=0.0013)$. 


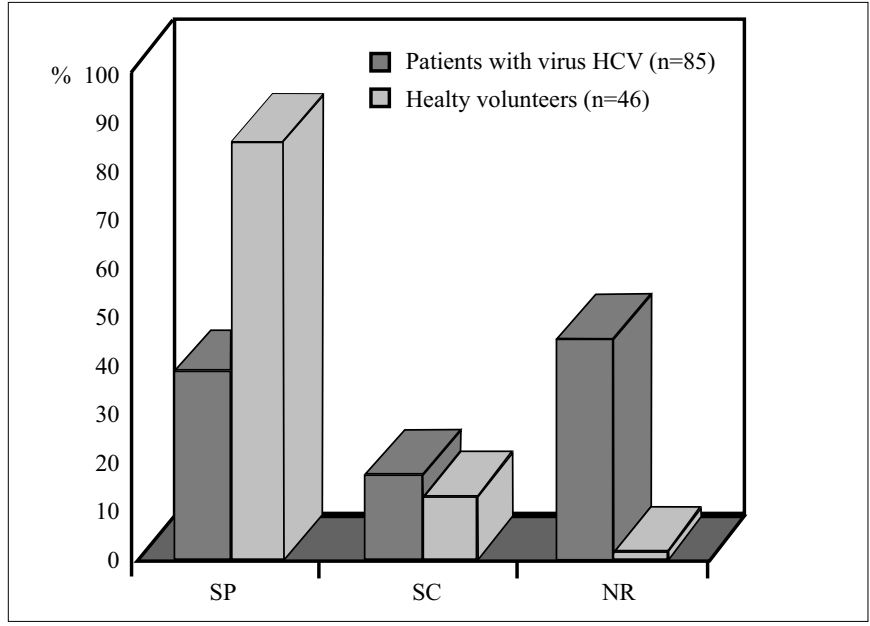

FIGURE 1 - Anti-HBs results 1 month following dose 3 of vaccine

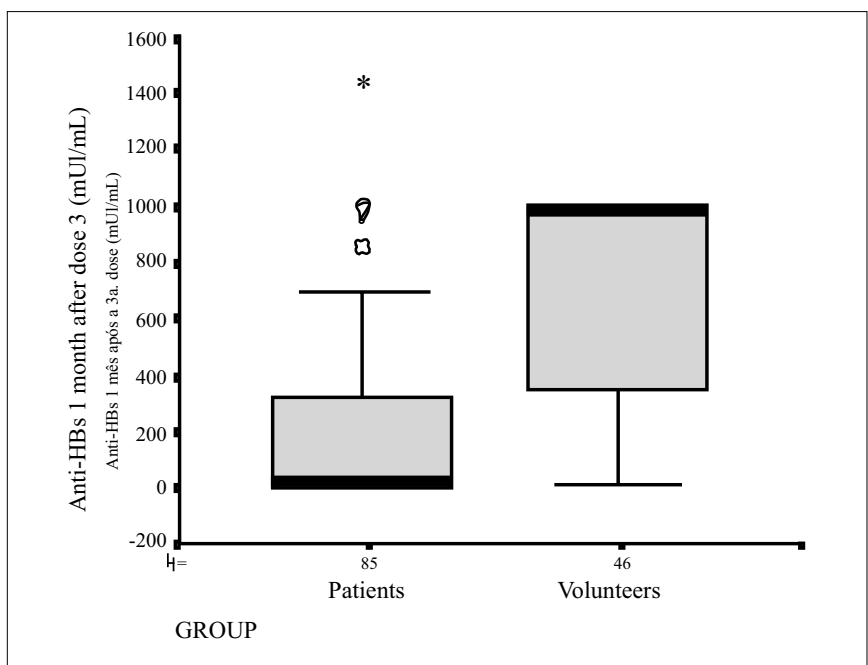

FIGURE 2 - Distribution of anti-HBs values between patients and volunteers 1 month following dose 3 of vaccine

In relation to the other variables (gender, BMI, drinking and smoking) there was no differences between the groups.

The response of the 65 patients diagnosed with chronic hepatitis was compared to that of the 20 patients who had already developed cirrhosis. In the former group, SP was found in $30.8 \%$, SC in $20.0 \%$, and NR in $49.2 \%$; in cirrhotic patients, the results were $60 \%, 10 \%$, and $30 \%$, respectively $(P=0.06)$.

Of the 73 patients who were submitted to HCV genotype determination, 33 had genotype 1 and 40 had genotypes 2 or 3 . Among patients with genotype 1 , SP was found in $24.2 \%$, SC in $18.2 \%$, and NR in $57 \%$, while among those with genotypes 2 or 3 , percentages were $50 \%, 20 \%$, and $30 \%$, respectively. The percentage of NR was significantly higher in patients with genotype $1(P=0.04)$.

Viral quantification was performed in 74 patients and showed a mean value of $5 \mathrm{MEq} / \mathrm{mL}$, varying between $<0.200$ and $68.11 \mathrm{MEq} / \mathrm{mL}$. In 45 patients quantification was above $2.760 \mathrm{MEq} / \mathrm{mL}$, with SP detected in $33.3 \%$, SC in $20 \%$, and NR in $46.7 \%$. There were 29 patients below this cut-off value with the following response distribution: $35.7 \%$, $21.4 \%$, and $42.9 \%$, respectively. No statistical difference was found in relation to vaccinal response when individuals were evaluated according to their viral load $(P=0.95)$.

The subgroups of non-responders and responders (SC and SP) were evaluated in relation to age, gender, smoking and BMI, and no statistical difference was found between them $(P>0.05)$.

Vaccination did not affect the level of aminotransferases. The mean activities of AST and ALT measured before vaccination were $70.35 \mathrm{U} / \mathrm{L} \pm 57.02$ and $100.56 \mathrm{U} / \mathrm{L} \pm 81.34$, respectively, and after vaccination, $68.20 \mathrm{U} / \mathrm{L} \pm 62,85(\mathrm{P}=0.714)$ and $96.80 \mathrm{U} / \mathrm{L} \pm 67.77$ $(P=0.633)$, respectively.

Only four individuals of all included in the study reported light pain on the injection region following administration of dose 1 , with a duration of up to 4-6 hours.

\section{DISCUSSION}

Vaccines against hepatitis have two purposes: to prevent morbidity and fortuitous mortality associated with acute viral infection, and to reduce the occurrence of chronic liver disease and hepatocellular carcinoma in infections that show progress ${ }^{(12,21)}$. At present, only vaccines against hepatitis A and B viruses are available.

Although hepatitis A does not progress to the chronic form, cases of fulminant hepatitis leading to death may occur, particularly in aged individuals or in patients with $\mathrm{CLD}^{(37)}$. Thus the Advirsory Committee on Immunization Practices (ACIP) recommends vaccination against hepatitis A virus in people suffering from $\mathrm{CLD}^{(7)}$.

The immunogenicity of vaccine against HAV is fairly satisfactory in patients with chronic liver diseases ${ }^{(18,19)}$. In this study we have not evaluated the response to vaccine against HAV because virtually all patients evaluated already had immunity against hepatitis A virus, which is in agreement to the findings that, in Brazil, most adults have already been exposed to this virus ${ }^{(10)}$.

In 1997 the World Health Organization recommended universal vaccination for $\mathrm{HBV}^{(16)}$. Besides all the potential benefits of vaccination, this would afford a considerable reduction in the incidence of hepatocellular carcinoma, since HBV is the world leading etiologic factor to this neoplasia and is highly prevalent in densely populated areas, such as Africa or southeast Asia, regions which account for $80 \%$ of cases $^{(6)}$. However, such recommendation is not followed by all countries. Moreover, it is believed that not even risk groups are vaccinated in a systematic way. Thus, although the vaccine against hepatitis B has been available for over two decades and is used in risk groups, it is estimated that only $10 \%$ of this population is vaccinated $^{(17)}$

WONG et al. ${ }^{(39)}$ investigated if patients with chronic liver disease dependent on hepatitis $\mathrm{C}$ virus were vaccinated against hepatitis $\mathrm{B}$ and found out that only $9 \%$ of the 126 patients evaluated had performed prophylaxis. They concluded their study by emphasizing the role of vaccination in carriers of $\mathrm{HCV}$ virus, since this is a population of immunosuppressed patients.

The importance of vaccination is supported by the fact that superinfection with $\mathrm{HBV}$ in patients with HCV not only worsens liver disease but also favour the progress to cirrhosis and hepatocarcinoma ${ }^{(6,9,14,31,32)}$

Although anti-hepatitis B vaccine has shown excellent results in healthy individuals, several authors ${ }^{(5,8,22,34,35,36)}$ have realized that the presence of advanced chronic liver disease helps to decrease immunogenicity in the primary series of vaccination. 
In this study, we evaluated patients with compensated chronic liver disease and found that seroconversion rates were lower in these patients and that $44 \%$ of them were non-reagents to vaccination, in contrast to the $2.2 \%$ of NR among healthy volunteers. Importantly, in the population of patients with chronic liver disease, we found out not only a higher number of patients who did not respond to vaccination, but also significantly lower anti-HBs levels, indicative of a status of immunosuppression.

In contrast to these findings, some authors ${ }^{(2,15,18,20)}$ noticed that patients with positive anti-HCV achieved an excellent percentage of seroconversion after the complete course of anti-hepatitis B vaccination. However, some of these studies investigated a limited number of cases, and most of them did not report patients' characteristics such as liver function evaluation, confirmation of viral etiology through PCR-HCV, viral genotype and quantification, and liver histology, thus precluding a better interpretation of their results.

In the only study found in literature with a methodological design similar to ours, WIEDMANN et al. ${ }^{(38)}$ evaluated the response to recombinant DNA vaccine against HBV (Recombivax) in a dose of $10 \mu \mathrm{g}$, IM, at months 0,1 , and 6 in 59 patients with chronic hepatitis by HCV virus and in 58 healthy volunteers. Among these patients SP was found in $51 \%$, SC in $19 \%$, and $\mathrm{NR}$ in $31 \%$, and in volunteers the results were $74 \%, 17 \%$, and $9 \%$, respectively.

Similarly to the German study ${ }^{(38)}$, we did not find a statistically significant difference when the vaccinal response was evaluated in relation to the histological findings. In other words, when the 65 patients with a diagnosis of chronic hepatitis were compared to the 20 patients who had already developed cirrhosis, no difference was found concerning seroconversion after the vaccine.

Two large multicentric studies published in $1998^{(25,27)}$ demonstrated that genotype and viral load should be taken into account during treatment for chronic hepatitis by HCV. Better results were observed in patients with genotype other than 1 and, to a lesser extent, in those with low viral load (cut-off point of 2 million copies $/ \mathrm{mL}$ ). In an analogy to the results of these studies, we evaluated the role of genotype determination and viral load in the response observed after vaccination.

In concern to the genotype, patients with genotype 1 showed a worse response to vaccine as compared to patients with genotypes 2 and 3 . Such data have never been reported in literature. In WIEDMANN et al. study ${ }^{(38)}$, this analysis was impaired because $97 \%$ of patients were of genotype 1 . Such results have a practical use because they affect the cost-effectiveness of vaccination in this population of patients. Thus, it could be inferred that specially patients with genotype 1 should use a different vaccination schedule with higher doses in order to obtain a better vaccinal response. As regards the cost-effectiveness of vaccination, it is important to cite the work developed by SIDDIQUI et al. ${ }^{(33)}$, in which they stress the importance of previous performance of markers for hepatitis B virus in order to screen the population to be benefited by vaccination.

Concerning viral load, it should be stressed that the discriminative critical level used here was based on the fact that, though the technique of branched-DNA bears resemblance to the PCR technique used in the above-mentioned studies ${ }^{(25,27)}$, a logarithmic correlation must be performed between the results ${ }^{(13,24)}$. In doing so, we have obtained the cut-off level used in this study. When the role of viral load in the response to vaccine was evaluated in patients with chronic liver disease, no difference was observed between values below and above critical levels of quantification. These results are similar to those reported by WIEDMANN et al. ${ }^{(38)}$.

Because a decreased response to vaccine is related to age, gender, smoking, and obesity ${ }^{(1,29,40)}$, we attempted to evaluate the influence of these predictive factors in patients with chronic liver disease. However, similarly to WIEDMANN et al. ${ }^{(38)}$, we did not find a statistically significant difference among responders as compared to non-responders. It is important to stress that, although there was a statistically significant difference in the age of patients with chronic liver disease as compared to that of healthy volunteers, the logistic regression performed to assess the role of age as a confusing factor in the comparison of response to vaccine between patients and volunteers revealed that age was unrelated to response when it was controlled for the fact that the patient was either a carrier or not of HCV. Possibly these factors of weak response were not significant here because they were analyzed in an immunosuppressed population. Thus, liver disease would be the primary factor in non-response and the other factors would not greatly affect the response to vaccine. The same was found when ROSMAN et al. ${ }^{(30)}$ studied another population of immunosuppressed individuals, in which age and BMI had no significant effect on seroconversion.

Only four of all individuals included in this study reported light pain in the injection region following the first dose of vaccine, with a duration of up to 4-6 hours. No alteration in aminotransferase activity was observed after vaccination. Thus we can conclude, as shown in literature ${ }^{(4,18,23,38)}$, that anti-hepatitis $\mathrm{B}$ vaccine is safe and does not interfere with the course of chronic hepatitis by HCV.

We conclude that seroconversion after vaccination against $\mathrm{HBV}$ is low in patients with chronic liver disease by HCV. Thus we recommend that this population of patients, particularly those with genotype 1 , should be submitted to a schedule with a double dose of vaccine, similar to the one used in patients under hemodialysis.

\section{ACKNOWLEDGEMENTS}

The authors wish to thank Dr. Guadalupe Garcia-Tsao for the helpful comments and suggestions. 
Mattos AA, Gomes EB, Tovo CV, Alexandre COP, Remião JOR. Eficácia da vacina anti-hepatite B em pacientes com doença hepática crônica pelo vírus da hepatite C. Arq Gastroenterol 2004;41(3):180-4.

Resumo - Racional - Considerando a imunossupressão dos pacientes com doença hepática crônica, sua resposta à vacinação é discutida na literatura. Objetivos - Avaliar a resposta à vacina anti-hepatite $\mathrm{B}$ em pacientes com hepatite crônica pelo vírus C. Métodos - Estudo prospectivo avaliando 85 pacientes com infecção pelo vírus C (46,8 $\pm 9,4$ anos, $44,7 \%$ homens) e 46 adultos saudáveis ( $36,7 \pm 11,1$ anos, $39,1 \%$ homens). Carga viral foi determinada através do b-DNA em 74 pacientes e o genótipo foi determinado por seqüenciamento em 73 pacientes. Todos os pacientes e os adultos saudáveis receberam três doses da vacina Engerix $\mathrm{B}^{\mathbb{R}} \mathrm{IM}$ (aos 0, 30 e 180 dias). Resposta sorológica à vacina foi dividida em três categorias: soroproteção, quando anti-HBs era $\geq 100 \mathrm{mUI} / \mathrm{mL}$; soroconversão, quando anti-HBs era 10-99 mUI/mL e não-reagente, quando anti-HBs era $<10 \mathrm{mUI} / \mathrm{mL}$. Resultados - A resposta da vacina anti-hepatite B em $1 \mathrm{mês}$ após a dose 3 foi soroproteção em $37,7 \%$, soroconversão em 17,6\% e não-reagente em $44,7 \%$ entre os pacientes, e $84,8 \%, 13,0 \%$ e $2,2 \%$, respectivamente em adultos saudáveis. O número de respostas não-reagentes foi significativamente maior em pacientes com doença hepática crônica. Sessenta e cinco pacientes com hepatite crônica foram comparados a 20 cirróticos compensados em relação à resposta à vacina, mas nenhuma diferença foi observada. A resposta à vacina nos pacientes com genótipos 2 ou $3(n=40)$ foi melhor do que naqueles com genótipo $1(n=33)$. A resposta não foi relacionada com a concentração de VHC-RNA. Conclusão - O número de não-respondedores foi maior em pacientes com infecção crônica pelo vírus C, independentemente do "status" histológico e da carga viral. É sugerido que tais pacientes deveriam receber uma dose dupla de vacina, particularmente aqueles com genótipo 1.

DESCRITORES - Vacinas contra hepatite B. Hepatopatias. Hepacivirus.

\section{REFERENCES}

1. Averhoff F, Mahoney F, Coleman P, Scjatz G, Hurwitz E, Margocis H. Immunogenicity of hepatitis B vaccines, implications for personal at occupacional risk of hepatitis B virus infection. Am J Prev Med 1998;15:1-8.

2. Awofeso N, Levy M, Harper S, Jones M, Hayes M, Douglas J, Fisher M, Folpp D. Response to HBV vaccine in relation to vaccine dose and anti-HCV positivity: a new South Wales correctional facilities. Vaccine 2001; 19:4245.

3. Bedossa P, Poynard T. An algorithm for the grading of activity in chronic C. Hepatology 1996;24:289-93.

4. Bennet RG, Powers DC, Remsburg RE, Scheve A, Clements ML. Hepatitis B virus vaccination for older adults. J Am Geriatr Soc 1996;44:699-703.

5. Berner J, Kadian M, Post J, Muller C, Schwartz M, Conn M, Borcich A. Prophylactic recombinant hepatitis $\mathrm{B}$ vaccine in patients undergoing orthotopic liver transplantation. Transplant Proc 1993;25:1751-2.

6. Bosch FX, Ribes J, Borràs J. Epidemiology of primary liver cancer. Semin Liver Dis 1999;19:271-85.

7. Centers for Disease Control. Recommendations of the Advisory Committee on Prevention of hepatitis. A through active or passive Immunization Practices (ACIP). MMWR Morb Mortal Wkly Rep 1996;455:1-30.

8. Chalasani N, Smallwood G, Halcomb J, Fried MW, Boyer TD. Is vaccination against hepatitis B infection indicated in patients waiting for or after orthotopic liver transplantation?. Liver Transpl Surg 1998;4:128-32.

9. Chiba T, MatsuzakiY, Abei M. The role of previous hepatitis B virus infection and heavy smoking in hepatitis C virus-related hepatocellular carcinoma. Am J Gastroenterol 1996;91:1195-203

10. Clemens SAC, Fonseca JC, Azevedo T, Cavalcanti A, Silveira TR, Castilho MC, Clemens R. Soroprevalência para hepatite A e hepatite B em quatro centros do Brasil. Rev Soc Bras Med Trop 2000;33:1-10.

11. EASL International Consensus Conference on Hepatitis C. Paris, 26-28 February 1999. Consensus statement. J Hepatol 1999; 30:956-61.

12. Eddleston A. Modern vaccines - hepatitis. Lancet 1990; 335:1142-5

13. Fang JWS, Albrecht JK, Jacobs S, Lau JY. Quantification of serum hepatitis C virus RNA. Hepatology 1999; 29:997-8.

14. Ilan Y, Ashuv Y, Tur-Kaspa R, Shou Ual D. Chronic hepatitis C virus infection with exposure to hepatitis B virus. Isr J Med Sci 1994; 30:259-63.

15. Kamel M, El Manialawi M, Miller FD. Recombinant hepatitis B vaccine immunogenicity in presence of hepatitis C virus seropositivity. Lancet 1994; 343:552 (letter).

16. Kane MA. Global status os hepatitis B immunization - commentary. Lancet 1996; 348:696.

17. Katkov WN, Dienstag JL. Prevention and therapy of viral hepatitis. Semin Liver Dis $1991 ; 11: 165-74$

18. Keeffe EB, Iwarson S, Mcmahon BJ, Lindsay KL, Koff RS, Manns M, Bauncarten R, Wiese M, Fourneau M, Safary A, Klemens R, Krause DS. Safety and immunogenicity of hepatitis A vaccine in patients with chronic liver disease. Hepatology 1998; 27:881-6.

19. Lee SD, Chan CY, Yu MI, Wang YJ, Chang FY, Lo KJ, Safary A. Safety and immunogenicity of inactived hepatitis A vaccine in patients with chronic liver disease. J Med Virol 1997; 52:215-18

20. Lee SD, Chan CY, Yu MI, Lu RH, Chang FY, Lo KJ. Hepatitis B vaccination in patient with chronic hepatitis C. J. Med Virol 1999; 59:463-468.

21. Lemon SM And Thomas DL. Vaccines to prevent viral hepatitis. N Engl J Med 1997; 336:196-204

22. Loinaz C, Juanes JR, Gonzales EM. Hepatitis B vaccination results in 140 liver transplant recipients. Hepatogastroenterology 1997; 44:235-8.
23. Marsano LS, West DJ, Chan I, Hesley TM, Cox J, Hackworth V, Greenberg RN. A two-dose hepatitis $\mathrm{B}$ vaccine regimen: proof of priming and memory responses in young adults. Vaccine 1998; 16:624-9.

24. Martinot-Peignoux M, Boyer N, L E Bretan V, Le guludec G, Castenau C, Akremi R, Marcellin P. A new step toward standardization of serum hepatitis C virus DNA quantification in patients with chronic hepatitis C. Hepatology 2000; 31:726-9.

25. Mc Hutchison JG, Gordon SC, Schiff ER, Shiffman ML, Lee WM, Rustgi VK, Goodman $\mathrm{ZD}$, Ling $\mathrm{MH}$, Cort $\mathrm{S}$, Albrecht JK. Interferon alfa $-2 \mathrm{~b}$ alone or in combination with ribavirin as initial treatment for chronic hepatitis C. Hepatitis Interventional Therapy Group. N Engl J Med 1998; 339:1485-92.

26. NIH. National Institute of Health consensus development conference panel statement: management of hepatitis C. Hepatology 1997; 26(suppl 1)2S-10S.

27. Poynard T, Marcellin P, Lee SS, Niederau C, Minuck GS, Ideo G, Bain V, Heathcote J, Zeuzem S, Trepo C, Albrecht J. Randomized trial of interferon $2 \mathrm{~b}$ plus ribavirin for 48 weeks or for 24 weeks versus interferon 2 b plus placebo for 48 weeks for treatment of chronic infection with hepatitis C virus. Lancet 1998; 352:1426-32.

28. Pugh RWH, Murray-Lyon IM, Dawson JL. Transection of the oesophagus for 0bleeding oesophageal varices. Br J Surg 1983; 60:646-9

29. Roome AJ, Walsh SJ, Cartter ML, Hadler JL. Hepatitis B vaccine responsiveness in Connecticut public safety personnel. JAMA 1993; 270:2931-4.

30. Rosman AS, Basu P, Galvin K, Lieber CS. Efficacy of a high and accelerated dose of hepatitis B vaccine in alcoholic patients: a randomized clinical trial. Am J Med 1997; 103:217-22.

31. Roudot-Thraval F, Bastie A, Pawlotsky JM, Dhumeaux D. Epidemiological factors affecting the severity of hepatitis $\mathrm{C}$ virus-related liver disease: A French survey of 6,664 patients. Hepatology 1997; 26:485-490.

32. Sagnelli E, Coppola N, Marrocco C. Acute hepatitis B in HCV chronic carriers: virological interaction on clinical course. Hepatology 2001; 34:314 A

33. Siddiqui F, Mutchnick M, Kinzie J, Peleman R, Naylor P, Ehrinpreis M. Prevalence of hepatitis A virus and hepatitis B virus immunity in patients with polymerase chain reaction-confirmed Hepatitis C: implications for vaccination strategy. Am J Gastroenterol $2001 ; 96: 858-63$

34. Van Thiel DH, El-Ashmawy L, Love K, Gavaler JS, Starzl TE. Response to hepatitis B vaccination by liver transplant candidates. Dig Dis Sci 1992; 37:1245-49.

35. Van Thiel DH \& Gavaler JS. Response to HBV vaccination in patients with severe liver disease. Absense of an HLA effect. Dig Dis Sci 1992; 37:1447-51.

36. Van Thiel DH. Vaccination of patients with liver disease: who, when, and how. Liver Transpl Surg 1998; 4:185-7.

37. Vento S, Garofano T, Renzini C, Cainelli F, Casali F, Ghironzi G, Ferraro T, Concia E. Fulminant hepatitis associated with hepatitis A virus superinfection in patients with chronic hepatitis C. N Engl J Med 1998; 338:286-90.

38. Wiedmann M, Liebert UG, Oesen U, Porst H, Wiese M, Schroeder S, Halm U, Mossner J, Berr F. Decreased immunogenicity of recombinant hepatitis B vacine in chronic hepatitis C. Hepatology 2000; 31:230-4

39. Wong V, Wreghitt TG, Alexander GJ . Prospective study of hepatitis B vaccination in patients with chronic hepatitis C. BMJ 1996; 312:1336-7.

40. Wood RC, Macdonald KL, White KE, Hedberg CW, Hanson M, Osterholm MT. Risk factors for lack of detectable antibody following hepatitis B vaccination of Minnesota health care workers. JAMA 1993; 270:2935-9.

Recebido em 1/8/2003.

Aprovado em 28/4/2004. 